\section{The Development of Activity of Cell Wall Bound $\beta$-Fructofuranosidase with Ripening and Senescence of Tomato Fruit}

\section{Tomoyoshi Iwatsubo,* Hiroki Nakagawa, Nagao Ogura and Hidetaro TAKehana

\author{
Department of Food Chemistry and Technology, \\ Faculty of Horticulture, Chiba University, \\ Matsudo, Chiba
}

Received September 25, 1974

Many enzyme activities in higher plants are increased by a variety of environmental perturbations. ${ }^{11}$

In the past there have been a large number of investigations concerning changes of the enzyme activity associated with fruit ripening. ${ }^{21}$

It has been reported that the change of activities of some enzymes bound to the cell walls of tomato fruit (cellulase, $^{2)}$ polygalacturonase, ${ }^{2)}$ and pectinesterase ${ }^{3 /}$ ) arises during maturation. $\beta$-Fructofuranosidase $(\beta$ FFase EC 3.2.1.26) from tomato fruit was also one of the cell wall-bound enzymes and level of $\beta$-FFase activity increased steadily during maturation.

This paper shows that the increase in $\beta$-FFase activity is due to the synthesis of $\beta$-FFase rather than the disappearance of endogenous inhibitors.

Mature green fruits of tomato (Lycopersicum escurentum var. Hikari) were ripened at $25^{\circ} \mathrm{C}$ for 7 days under the dark conditions after the peduncles were immersed in each aqueous solution of chemicals for 2 days. Tomato pericarp tissue was chopped into small pieces and blended for 2 min at the top speed in a Waring blendor with an equal amount (w/v) of distilled water. The homogenate was centrifuged at $10,000 \times g$ for $10 \mathrm{~min}$ and the precipitation was extracted in $200 \mathrm{~mm}$ potassium phosphate buffer, $\mathrm{pH} 8.0$. The mixture was then centrifuged at $10,000 \times g$ for $10 \mathrm{~min}$ and the supernatant was dialyzed against distilled water. ${ }^{51}$

$\beta$-FFase activity was assayed by a colorimetric procedure according to the method of Yabuki. ${ }^{6)}$ The reaction mixture for the standard assay method consisted of $0.075 \mathrm{M}$ sucrose, $120 \mathrm{~mm}$ acetate buffer $(\mathrm{pH}$ 4.5 ) and enzyme solution in a total volume of $1 \mathrm{ml}$. The reaction mixture was incubated at $30^{\circ} \mathrm{C}$ for $15 \mathrm{~min}$. After the incubation, $1.0 \mathrm{ml}$ of the reaction mixture was added to 3,6-dinitrophthalic acid reagent to determine reducing sugar formed. ${ }^{71}$ Activities were

* Present address: Calpis Food Industry Laboratory, Tokyo. expressed as $\beta$-FFase units, micromoles of glucose liberated per min. ${ }^{51}$

The increase in $\beta$-FFase activity commenced at the mature green stage of tomato fruit, reached a maximum after about 10 days, and thereafter declined slightly (Fig. 1). After harvest at the mature green stage, the

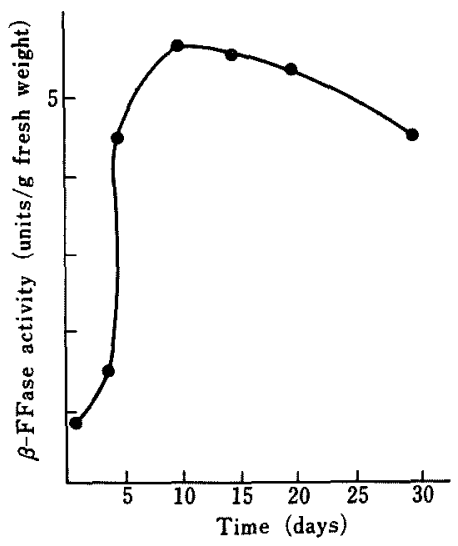

FIG. 1. Increase in $\beta$-FFase Activity in Extracts from Various Stages of Detached Tomato Fruit.

\section{Table I. Effects of Various Fractions on $\beta$-FFase Activity in Extract of Cell Walls of Red RIPE Tomato FruIt}

Enzyme assays were carried out under the standard assay conditions. G: Extract of cell walls of green tomato fruit with $200 \mathrm{~mm}$ potassium phosphate buffer (pH 8.0). $\mathrm{G}_{\mathrm{s}}$ : Supernatant of homogenate from green tomato fruit after the centrifugation at $10,000 \times$ $g$ for $10 \mathrm{~min}$. R: Extract of cell walls of red ripe tomato fruit with $200 \mathrm{~mm}$ potassium phosphate buffer (pH 8.0). $\mathbf{R}_{\mathrm{s}}$ : Supernatant of homogenate from red ripe tomato fruit after the centrifugation at $10,000 \times g$ for $10 \mathrm{~min}$. The heat treatment of $\mathrm{G}_{\mathrm{B}}$ was undertaken at $100^{\circ} \mathrm{C}$ for $10 \mathrm{~min}$. The dialysis of $\mathrm{G}_{\mathrm{s}}$ was undertaken for 1 day.

\begin{tabular}{|c|c|c|}
\hline Fraction (ml) & $\begin{array}{c}\text { 6-FFase activity } \\
\text { (units/g fresh } \\
\text { weight) }\end{array}$ & $\begin{array}{r}\text { Relative } \beta \text {-FFase } \\
\text { activity }(\%)\end{array}$ \\
\hline $\mathrm{G}(0.25)$ & 0.96 & 17.1 \\
\hline $\mathrm{G}_{\mathrm{s}}(0.25)$ & 0.33 & 5.9 \\
\hline $\mathrm{R}(0.25)$ & 5.60 & 100 \\
\hline $\mathrm{R}_{\mathrm{B}}(0.25)$ & 0.52 & 9.2 \\
\hline $\mathrm{R}(0.25)+\mathrm{G}_{\mathrm{s}}(0.25)$ & 3.81 & 68.0 \\
\hline$R(0.25)+G(0.25)$ & 6.54 & 116.8 \\
\hline $\mathrm{R}(0.25)+\mathrm{R}_{\mathrm{S}}(0.25)$ & 4.60 & 82.2 \\
\hline $\begin{array}{r}\mathrm{R}(0.25)+\text { Dialyzed } \\
\mathrm{G}_{\mathrm{s}}(0.25)\end{array}$ & 6.17 & 110.2 \\
\hline $\begin{array}{r}\mathrm{R}(0.25)+\text { Heated } \\
\mathrm{G}_{\mathrm{S}}(0.25)\end{array}$ & 5.64 & 100.8 \\
\hline
\end{tabular}


TABLe II. EfFects of CyCloheXimide AND Thiouracil on $\beta$-FFASE Actrvity of TOMATO Fruit

Measurements of enzyme activities were carried out under the standard assay conditions. Tomato fruit were ripened at $25^{\circ} \mathrm{C}$ for 7 days under the dark conditions after the peduncles were immersed in aqueous solutions of various chemicals for 2 days. Tomato fruit placed in distilled water served as the control.

\begin{tabular}{lccc} 
Treatment & $\begin{array}{c}\text { Concentra- } \\
\text { tion } \\
(\mathrm{M})\end{array}$ & $\begin{array}{c}\text { Relative } \\
\beta \text {-FFase } \\
\text { activity }(\%)\end{array}$ & $\begin{array}{c}\text { Inhibition } \\
(\%)\end{array}$ \\
\hline Control & - & 100 & 0 \\
Cycloheximide & $10^{-3}$ & 34.5 & 65.5 \\
Thiouracil & $10^{-3}$ & 31.0 & 69.0 \\
\hline
\end{tabular}

increase of $\beta$-FFase activity in detached fruit ripened at $25^{\circ} \mathrm{C}$ was the same as that in fruit ripened on the plant.

Extracts of red ripe tomato fruit $(R)$ were prepared and mixed $(1: 1)$ with supernatant of mature green tomato fruit $\left(\mathrm{G}_{s}\right)$ and subsequently incubated for $10 \mathrm{~min}$ at $30^{\circ} \mathrm{C}$. The mixture was assayed under the standard assay conditions. Table I shows that the level of $\beta$-FFase activity was inhibited about $32 \%$ by $\mathrm{G}_{\mathrm{s}}$. $\mathrm{G}_{\mathrm{s}}$ was seemed to contain heat labile and dialyzable substance from the results of heat treatment and dialysis.

Effects of inhibitors of protein- and nucleic acidsyntheses on the increase in $\beta$-FFase activity were shown in Table II. The increase in $\beta$-FFase activity was remarkedly inhibited by both chemicals in vivo. However, in the experiments of the addition of both chemicals $\left(10^{-3} \mathrm{M}\right)$ to the purified $\beta$-FFase solution, ${ }^{\mathbf{5}}$ ) there were little effects on the enzyme activity.

It was suggested that $\beta$-FFase activity was inhibited about $32 \%$ by $\mathrm{G}_{\mathrm{s}}$ (Table $\mathrm{I}$ ).

In this case, it was impossible to explain the increase in $\beta$-FFase activity during the fruit maturation and ripening by means of the decrease in the inhibitor. When the activity of an enzyme has been shown to increase rapidly in a plant tissue in response to some particular treatment, the introduction of a specific inhibitor of protein synthesis has been used to recognize whether the increase of $\beta$-FFase activity is due to synthesis of active enzyme itself. ${ }^{81}$

The level of $\beta$-FFase activity was remarkedly decreased in whole tomato fruit by cycloheximide or thiouracil $\left(10^{-3} \mathrm{M}\right)$ (Table II).

The treatment of tomato fruit by cycloheximide and thiouracil, detered color development and softning and did not develope after-ripening normally.

It was concluded that the increase of $\beta$-FFase activity during the fruit ripening is due to synthesis of $\beta$-FFase rather than disappearance of endogenous inhibitors.

Acknowledgement. The authors wish to thank Mr. T. Kuwabara, Faculty of Horticulture, Chiba University, for providing the tomato fruit, and to Professor H. Yoshida, the Department of Agricultural Chemistry, Tamagawa University, for his kindness in correcting the manuscript.

\section{REFERENCES}

1) P. Filner, J. L. Wray and J. E. Varner, Science, 165, 358 (1969).

2) J. A. Sacher, Ann. Rev. Plant Physiol., 24, 197 (1973).

3) H. Nakagawa, K. Sekiguchi, N. Ogura and H. Takehana, Agr. Biol. Chem., 35, 301 (1971).

4) H. Nakagawa, T. Hashimoto, N. Ogura and H. Takehana, Bull. Fac. Hort., Chiba Univ., 20, 67 (1972).

5) H. Nakagawa, Y. Kawasaki, N. Ogura and H. Takehana, Agr. Biol. Chem, 36, 18 (1970).

6) M. Yabuki, Nippon Nôgeikagaku Kaishi, 39, 138 (1965).

7) T. Momose, Y. Mukai and M. Watanabe, Talenta, 5, 275 (1960).

8) K. T. Glasziou, Ann. Rev. Plant Physiol., 20, 63 (1969). 